\title{
Urinary Hydroxyproline: Creatinine Ratio in Normal Term, Pre-term, and Growth-retarded Infants ${ }^{\star}$
}

\author{
M. K. YOUNOSZAI, ANNE KACIC, LOUISE DILLING, and J. C. HAWORTH \\ From the Research Foundation, The Children's Hospital of Winnipeg, and the Department of Paediatrics, University of \\ Manitoba, Canada
}

The daily urinary excretion of endogenous hydroxyproline is believed to be a reliable index of collagen turnover, particularly the collagen matrix of bone (Ziff et al., 1956; Prockop and Sjoerdsma, 1961; Dull, Causing, and Henneman, 1962; Klein, Albertsen, and Curtiss, 1962; Prockop and Kivirikko, 1967). During periods of rapid growth, the daily excretion of hydroxyproline increases (Prockop and Kivirikko, 1967), and in infants, 3-17 weeks of age, a direct relation has been shown between daily hydroxyproline excretion and the rate of linear growth (Younoszai et al., 1967). We have previously shown that total hydroxyproline excretion is low on the first day of life but by the third day has increased significantly in normal term and pre-term infants. In intrauterine growth-retarded infants this increase is significantly less. We suggested that these findings might reflect a state of relative collagen inactivity at birth followed by the initiation of a phase of rapid growth which is less in the case of growthretarded infants (Younoszai and Haworth, 1968).

However, recent work has indicated that the urinary excretion of total hydroxyproline in the newborn infant is probably not a reliable index of perinatal growth. Whereas in children and adults the major portion of the hydroxyproline in the urine is peptide-bound, and $5 \%$ or less is in the free form (Ziff et al., 1956; Prockop and Kivirikko, 1967), normal infants during the first few months of life excrete about $25 \%$ of the total as free hydroxyproline, and in premature infants the percentage is even greater (Morrow, Kivirikko, and Prockop, 1966, 1967). It has, therefore, been suggested that peptide-bound hydroxyproline excretion may be a more reliable index of growth in the perinatal period than total hydroxyproline excretion. Smith, Dehan, and Reynolds (1968) have also suggested that the low hydroxyproline excretion at

Received February 17, 1969.

*Supported by Canadian National Health Grant 606-7-120. birth may be associated with depression of collagen activity as a result of the birth process, rather than with growth rate before birth. Doubt about the effect of the limited function of the newborn kidney is another source of difficulty in interpreting urinary hydroxyproline excretion in newborn infants.

Measurement of the urinary hydroxyproline/ creatinine ratio might overcome some of the difficulties in interpretation of hydroxyproline excretion in the newborn infant, since the ratio partially corrects for body size and for differences in renal function (Allison, Walker, and Smith, 1966). The present investigation was designed to study the hydroxyproline/creatinine ratio in three groups of newborn infants who might be expected to show differences in growth rates in the perinatal period, and to determine whether the ratio remains constant in random urine samples, thus eliminating the need for 24-hour urine collections.

\section{Material and Methods}

Three groups of infants were studied:

(1) 14 normal term infants, mean gestational age $39 \cdot 8$ weeks (range $37-42$ weeks), mean birthweight $3 \cdot 17 \mathrm{~kg}$. (range $2 \cdot 98-3.83 \mathrm{~kg}$.).

(2) 13 term growth-retarded infants, mean gestational age 39.4 weeks (range $37-41$ weeks), mean birthweight $2 \cdot 36 \mathrm{~kg}$. (range $1 \cdot 89-2 \cdot 62 \mathrm{~kg}$.).

(3) 17 pre-term infants, mean gestational age 33.7 weeks (range 24-36 weeks), mean birthweight $2 \cdot 06 \mathrm{~kg}$. (range $1.02-2.50 \mathrm{~kg}$.).

The weights of the normal term and pre-term infants were between the 10th and 90th centile for their gestational ages on the Denver intrauterine growth chart (Lubchenco et al., 1963). The weights of the growthretarded infants were below the 10th centile for their gestational ages. Males and females were approximately equally represented within each group of infants.

The infants were free of detectable congenital anomalies and had no major disease. One of the preterm infants developed hypoglycaemia (blood glucose 
$<20 \mathrm{mg} . / 100 \mathrm{ml}$. ) and recovered promptly with treatment. Three of the pre-term infants suffered from mild respiratory distress syndrome from the first to the third days of life and recovered without sequelae. All infants received cow's milk formulae except for 1 normal and 1 growth-retarded infant who were breast-fed.

Random urine samples were collected in plastic bags from the infants on the first and third days of life and from those that were still in the nursery on the seventh day of life. 24-hour urine collections were also obtained from 4 normal-term, 2 growth-retarded, and 1 preterm infant, also on the first, third, and seventh days of life. The urines were acidified $(p \mathrm{H}<1)$ and stored at $-20^{\circ} \mathrm{C}$. The methods used for determining hydroxyproline and creatinine have been previously described (Younoszai and Haworth, 1968). Free hydroxyproline was determined in unhydrolysed urine specimens. Peptide hydroxyproline was calculated by subtracting the amount of free hydroxyproline from the total hydroxyproline. The ratios of total and peptide hydroxyproline $(\mathrm{mM} / \mathrm{l}$.)/creatinine $(\mathrm{mM} / 1$. $)$ were calculated.

\section{Results}

Constancy of total hydroxyproline/creatinine ratios in 24-hour urine collections and in random urine samples. Ratios in 24-hour collections and in random urine samples obtained during the same 24-hour period are compared in Fig. 1. There was good correlation for ratios below 0.5 . At higher ratios the spread was greater. Comparing the peptide hydroxyproline/

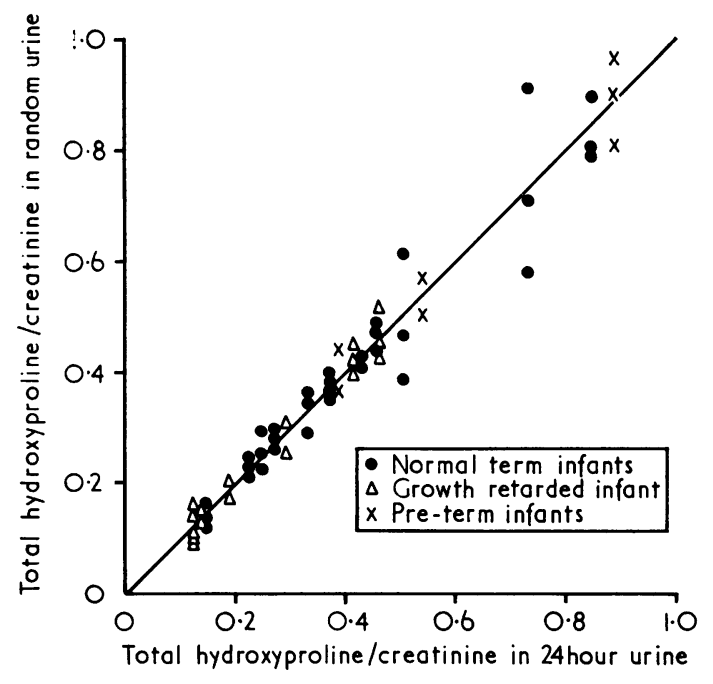

FIG. 1.-Total hydroxyproline/creatinine ratios in 24hour urine collections and random urine samples collected during the same 24-hour period in relation to the line of identity.
TABLE

Mean ( \pm Standard Error) Percentage of Total Hydroxyproline Excreted as Free Hydroxyproline in Random Urine Samples from Three Groups of Infants

\begin{tabular}{c|c|c|c}
\hline $\begin{array}{c}\text { Age } \\
\text { (days) }\end{array}$ & $\begin{array}{c}\text { Normal } \\
\text { Term }\end{array}$ & $\begin{array}{c}\text { Growth- } \\
\text { retarded }\end{array}$ & Pre-term \\
\hline 1 & $\begin{array}{c}21 \cdot 6 \pm 1 \cdot 41 \\
(14)\end{array}$ & $\begin{array}{c}25 \cdot 6 \pm 1 \cdot 17 \\
(13)\end{array}$ & $\begin{array}{c}35 \cdot 5 \pm 1 \cdot 89 \\
(17)\end{array}$ \\
3 & $\begin{array}{c}27 \cdot 6 \pm 2 \cdot 15 \\
(14)\end{array}$ & $\begin{array}{c}29 \cdot 6 \pm 1 \cdot 84 \\
(13)\end{array}$ & $\begin{array}{c}37 \cdot 6 \pm 2 \cdot 73 \\
(11)\end{array}$ \\
7 & $\begin{array}{c}32 \cdot 2 \pm 3 \cdot 13 \\
(6)\end{array}$ & $\begin{array}{c}24 \cdot 9 \pm 1 \cdot 66 \\
(6)\end{array}$ & $\begin{array}{c}39 \cdot 1 \pm 3 \cdot 36 \\
(9)\end{array}$ \\
\hline
\end{tabular}

Figures in parentheses indicate the number of observations.

creatinine ratios in 24-hour and random urine samples, a similar relation was found.

Percentage of free hydroxyproline. The Table shows the percentage of total hydroxyproline excreted as free hydroxyproline in random urine samples from the 3 groups of infants on the first, third, and seventh days of life. The normal term and the growth-retarded infants excreted similar proportions of free hydroxyproline. The preterm infants excreted a significantly higher proportion of free hydroxyproline than either of the other 2 groups of infants on the first and third days of life, and a significantly higher proportion than the growth-retarded infants on the seventh day of life $(p<0.05)$. The percentage of free hydroxyproline increased significantly from the first to the seventh day in the normal term infants but not in the other 2 groups of infants. Fig. 2 shows the percentage of free hydroxyproline in relation to

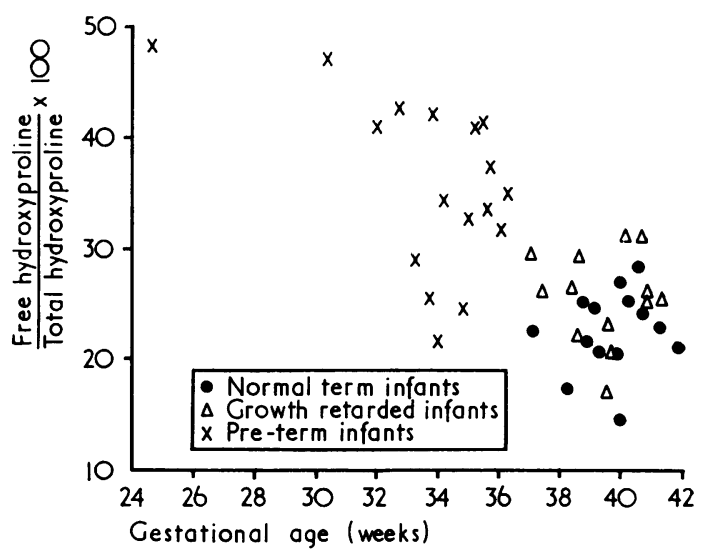

FIG. 2.-Urinary free hydroxyproline as a percentage of total hydroxyproline in relation to gestational age. 


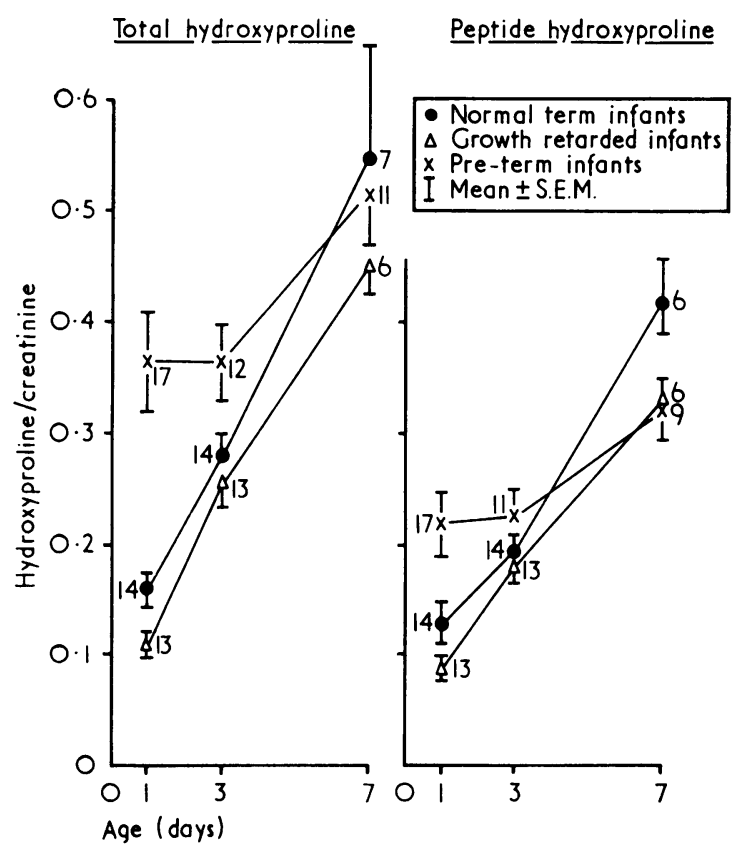

FIG. 3.-Left, total hydroxyproline/creatinine ratios and, right, peptide hydroxyproline/creatinine ratios in random urine samples on the first, third, and seventh days of life in the three groups of infants.

gestational age for the three groups of infants on the first day of life. The correlation is statistically significant $(\mathrm{r}=-0 \cdot 71, \mathrm{p}<0.001)$, but there is a good deal of scatter.

Total hydroxyproline/creatinine ratio (Fig. 3a.) The total hydroxyproline/creatinine ratios on the first and third days of life in the pre-term infants were significantly greater than those in either the normal term or the growth-retarded infants, and the ratios in the normal term infants were significantly greater than in the growthretarded infants on the first day but not on the third day. During the first week of life, ratios increased four- or fivefold in the normal term and growth-retarded infants. Though ratios increased less in the pre-term infants, the increase from the third to the seventh day was statistically significant. On day 7 , the total hydroxyproline/creatinine ratios were not significantly different in the three groups of infants.

Peptide hydroxyproline/creatinine ratios (Fig. 3b). Despite the greater proportion of free hydroxyproline in the urine of the pre-term infants, their peptide hydroxyproline/creatinine ratios on the first day of life were significantly greater than the other two groups of infants, but not on day 3 . On day 7 the ratios in the normal term infants were significantly greater than in either the preterm or growth-retarded infants.

\section{Discussion}

The close correlation between the total hydroxyproline/creatinine ratio in 24-hour urine collections and in random samples obtained during the same 24-hour period is similar to the observations made in normal and malnourished children (Whitehead, 1966; Howells, Wharton, and McCance, 1967). Hydroxyproline/creatinine ratios may therefore reliably be measured in random urine samples.

The values for total hydroxyproline/creatinine ratios in the normal term infants reported here are similar to those published by others (Allison et al., 1966; Howells et al., 1967; Klein and Teree, 1966). However, in view of the much higher proportion of free hydroxyproline excreted by newborn infants in comparison with older children and adults, total hydroxyproline is not a valid measure of growth in the newborn period. In our series urinary free hydroxyproline on the first day of life averaged about $22 \%$ of the total hydroxyproline excretion in normal term infants and about $35 \%$ in pre-term infants. These values are similar to those of Morrow et al. (1966, 1967). In addition, we showed a significant inverse relation between the percentage of free hydroxyproline in the urine on the first day of life and gestational age (Fig. 2). The proportion of free hydroxyproline excreted by growth-retarded infants is similar to that of normal term infants. Morrow et al. (1967) presented convincing evidence of an impairment of metabolism of hydroxyproline in the neonatal period, which may be due to a partial deficiency of the enzyme hydroxyproline oxidase, thus giving rise to higher blood levels and higher urinary excretion rates. The significant rise in the percentage of free hydroxyproline over the first days of life which we observed in the normal term infants could be explained by the great increase in collagen turnover which is seen during this period, as evidenced by the greatly increased urinary total hydroxyproline excretion, overwhelming an already impaired metabolic pathway. It is not clear why a significant increase in the percentage of free hydroxyproline was not also seen in the pre-term infants.

The pattern of the peptide hydroxyproline/ creatinine ratios during the first week of life was similar to the pattern of the total hydroxyproline/ creatinine ratios. Compared with the normal 
term infants the peptide hydroxyproline/creatinine ratios in the pre-term infants on the first day of life were significantly higher, and in the growthretarded infants significantly lower. This is what might be expected for their growth patterns during the latter days or weeks of pregnancy, since normal term infants grow little during this period, whereas pre-term infants are growing rapidly. The rapid rise in the ratio in the term and growth-retarded infants over the first week would suggest a phase of rapid growth. In the pre-term infants, the ratios did not change significantly between the first and third days but increased significantly between the third and seventh day.

The urinary hydroxyproline and creatinine on the first day of life may not be entirely endogenous since some may be derived from the mother. By the third day of life, however, the urinary hydroxyproline must be of endogenous origin, since milk does not contain this amino acid (Soupart, Moore, and Bigwood, 1954; McCance and Widdowson, 1960). The creatinine content of milk is 1-3 mg./ $100 \mathrm{ml}$. (Erickson, Stone, and Macy, 1933; Macy and Kelly, 1961) and would therefore not contribute significantly to the total body pool.

\section{Summary}

In normal term and growth-retarded infants during the first week of life, $20-30 \%$ of the total urinary hydroxyproline is excreted as free hydroxyproline. Pre-term infants excrete $35-40 \%$ of the total hydroxyproline in the free form. Total hydroxyproline excretion is therefore not a valid measure of skeletal growth in the newborn infant. The hydroxyproline/creatinine ratio correlated well in 24-hour urine collections and in random urine samples obtained during the same 24-hour period, thus making 24-hour urine collections unnecessary for this purpose. The peptide hydroxyproline/ creatinine ratio during the first week of life agrees well with the pattern of growth expected during this period of life. Ratios in pre-term infants are significantly higher and in growth-retarded infants significantly lower than in normal term infants on the first day of life. There is a rapid increase in the ratio during the first week, less in pre-term infants. Thus, the peptide hydroxyproline/creatinine ratio appears to be a valid index of growth in the perinatal period.
We acknowledge our thanks to the nursing staff of the Women's Pavilion, Winnipeg General Hospital, without whose help in collecting the urine samples this investigation could not have been undertaken. We are also grateful to Dr. Victor Chernick for reviewing the manuscript.

\section{REFERENCES}

Allison, D. J., Walker, A., and Smith, Q. T. (1966). Urinary hydroxyproline: creatinine ratio of normal humans at various ages. Clin. chim. Acta, 14, 729.

Dull, T. A., Causing, L., and Henneman, P. H. (1962). Urinary total hydroxyproline as an index of connective tissue turnover in bone. $\mathcal{F}$. clin. Invest., 41, 1355.

Erickson, B. N., Stone, N., and Macy, I. G. (1933). Human milk studies. XIV. A critique of the determinations of nitrogenous constituents. F. Biol. Chem., 103, 235.

Howells, G. R., Wharton, B. A., and McCance, R. A. (1967). Value of hydroxyproline indices in malnutrition. Lancet, $1,1082$.

Klein, L., Albertsen, K., and Curtiss, P. H., Jr. (1962). Urinary hydroxyproline in hyperparathyroidism: a study of three cases with and without bone lesions. Metabolism, 11, 1023.

- , and Teree, T. M. (1966). Skeletal metabolism in early infancy: urinary hydroxyproline. f. Pediat., 69, 266.

Lubchenco, L. O., Hansman, C., Dressler, M., and Boyd, E. (1963). Intrauterine growth as estimated from liveborn birth-weight data at 24 to 42 weeks of gestation. Fediatrics, 32, 793.

McCance, R. A., and Widdowson, E. M. (1960). The composition of foods. Spec. Rep. Ser. med. Res. Coun. (Lond.), 297.

Macy, I. G., and Kelly, H. J. (1961). Human milk and cow's milk in infant nutrition. In Milk: The Mammary Gland and its Secretion,Vol. II, p. 265. Ed. S. K. Kon and A. T. Cowie. New York, Academic Press.

Morrow, G., III, Kivirikko, K. I., and Prockop, D. J. (1966). Hydroxyprolinemia and increased excretion of free hydroxyproline in early infancy. $\boldsymbol{f}$. clin. Endocr., 26, 1012.

- , $\longrightarrow$, and - (1967). Catabolism and excretion of free hydroxyproline in infancy. ibid., 27, 1365.

Prockop, D. J., and Kivirikko, K. I. (1967). Relationship of hydroxyproline excretion in urine to collagen metabolism. Ann. intern. Med., 66, 1243.

- , and Sjoerdsma, A. (1961). Significance of urinary hydroxyproline in man. $\mathcal{f}$. clin. Invest., 40, 843.

Smith, R., Dehan, M., and Reynolds, E. O. R. (1968). Changes in urinary hydroxyproline in premature infants. Clin. chim. Acta, 21, 491 .

Soupart, P., Moore, S., and Bigwood, E. J. (1954). Amino acid composition of human milk. F. biol. Chem., 206, 699.

Whitehead, R. G. (1966). Urinary excretion of hydroxyproline in kwashiorkor. Lancet, 1, 203.

Younoszai, M. K., Andersen, D. W., Filer, L. J., Jr., and Fomon, S. J. (1967). Urinary excretion of endogenous hydroxyproline by normal male infants. Pediat. Res., 1, 266.

urine by premature and normal full-term infants and those with intrauterine growth retardation during the first three days of life. ibid., 2, 17.

Ziff, M., Kibrick, A., Dresner, E., and Gribetz, H. J. (1956). Excretion of hydroxyproline in patients with rheumatic and non-rheumatic diseases. F. clin. Invest., 35, 579.

Correspondence to Dr. J. C. Haworth, The Children's Hospital of Winnipeg, Winnipeg 3, Manitoba, Canada. 